\title{
A blusa e a urna: metamorfoses do associativismo de trabalhadores em Pernambuco entre o Império e a República
}

\author{
The blue collar and the ballot box: metamorphoses of workers' \\ associativism in Pernambuco at the dawn of the republic
}

\section{Felipe Azevedo Souza*}

\begin{abstract}
Resumo: A Liga Operária foi a primeira organização de Pernambuco a disputar eleições com uma pauta programática voltada aos interesses dos trabalhadores e seus candidatos eram representantes da classe operária. Isso ocorreu já no primeiro ano republicano. $O$ acompanhamento da trajetória da Liga abarca um momento de transição na atuação política dos trabalhadores urbanos organizados. O novo regime, a abolição da escravidão e a difusão de ideais socialistas tangenciaram considerável renovação de símbolos (o orgulho em trajar a blusa proletária) e estratégias de ação política (a disputa pelas urnas) daquele grupo de trabalhadores. Para dimensionar os limites e possibilidades deste cenário, o presente artigo busca colocar em perspectiva a atuação pregressa dos membros da Liga pelo universo associativo da capital pernambucana - através de mutualistas, irmandades e sociedades abolicionistas. E, em um segundo momento, analisar a trajetória eleitoral do grupo.
\end{abstract}

Palavras-chave: Trabalhadores; cultura política; eleições; associativismo; República.

Abstract: The Liga Operária was the first organization in Pernambuco to run elections with a programmatic agenda focused on the workers concerns and its candidates were representatives of the working class. This happened in the first republican year. The Liga's trajectory encompasses a moment of transition in the political actions of organized urban workers. The new regime, the abolition of slavery, and the spread of socialist ideals have biased a considerable renewal of symbols (the pride in wearing the proletarian blue collar) and strategies for political action (the dispute at the polls) of that group. In order to dimension the limits and possibilities of this scenario, this article seeks to put in perspective the past

Doutor em História Social pela Universidade Estadual de Campinas (Unicamp). Desenvolve estágio pós-doutoral no Programa de Pós-Graduação de História da Universidade Federal da Bahia (UFBA) com bolsa PNPD-CAPES. ORCID: https://orcid.org/0000-0002-6232-3273. E-mail: felipeazv.souza@gmail.com. 
performance of the members of the Liga through the associative universe of the capital of Pernambuco - through mutualists, catholic brotherhoods and abolitionist societies. And, also, to analyze the electoral trajectory of the group.

Keywords: Workers; Political Culture; Elections; Associativism; Republic.

N O MÊS DE JULHO DO ANO DE 1890, cerca de uma dúzia de artífices saíram em ronda pelas portas das fábricas e oficinas da cidade do Recife, levavam consigo folhetos impressos anunciando a constituição do "corpo consultivo do Partido Operário". Em meio a essa jornada, se dirigiam aos funcionários de cada oficina incentivando-os a escolher "dois ou três de vossos amigos, a fim de vos representar" no estabelecimento de uma nova iniciativa política que teria por fim a intervenção direta dos operários "na representação geral e local". ${ }^{1}$

A montagem de uma estrutura partidária nesses moldes, com pautas próprias formuladas por trabalhadores, representava uma situação até então inédita no Brasil e que vinha florescendo em alguns centros urbanos país afora. Sinal dos novos tempos, esse tipo de iniciativa só se tornou possível com a instauração da República. Possibilidades abertas principalmente pelo fim dos tradicionais partidos imperiais, além da institucionalização da liberdade para que qualquer cidadão que gozasse de plenos direitos conseguisse se lançar candidato a cargos públicos eletivos. Mudança que foi implementada em um momento de expansão do associativismo entre os trabalhadores de Recife e em meio à disseminação de novos debates sobre a intervenção do Estado nas relações de trabalho. ${ }^{2}$ No texto que segue, serão analisados os aspectos que engendraram as condições para que os trabalhadores desempenhassem novos papéis no jogo político, evidenciando como eles conseguiram se beneficiar desse potencial de protagonismo eleitoral que era consideravelmente mais elevado em comparação com o que existia no período imperial. ${ }^{3}$

A historiografia sobre o movimento operário já demonstrou que esse processo aconteceu simultaneamente em alguns centros urbanos do país. Assim como no Recife, organizações de trabalhadores disputando eleições já nos primeiros anos da década de 1890 podiam ser encontradas em cidades como Salvador, Rio de Janeiro e Santos. Essas coletividades funcionavam em torno de estruturas semelhantes e pleiteavam pautas muito parecidas, mas ainda que mantivessem algum contato entre si, geralmente tinham um raio de atuação limitado ao plano local. E esse é um aspecto característico da dinâmica desses grupos. Por mais que estivessem atentos e consonantes às divisas da Segunda Internacional Socialista, utilizando com regularidade suas expressões e símbolos, no dia a dia de suas práticas uma parte considerável dos afazeres dos líderes dos partidos operários consistia em sentar com os donos do poder e pactuar os termos com que viriam a atuar politicamente. ${ }^{4}$

1 Jornal do Recife, Recife, 26 jul. 1890.

2 Sobre o novo momento de reorganização das pautas por direitos dos trabalhadores e o recrudescimento do associativismo nesses anos, ver: MAC CORD, Marcelo. Direitos trabalhistas em construção: as lutas pela jornada de trabalho das oito horas em Pernambuco, 1890-1891. Tempo, v. 22, n. 39, p. 175-195, jan.- abr., 2016. p. 190.

3 Marcelo Mac Cord afirma que "pelo menos desde a década de 1860, os artistas mecânicos pernambucanos tentavam conquistar o lugar de deputado, mas nunca conseguiram ocupá-lo. Por mais que alguns deles quisessem sair candidatos, ora eram preteridos pelos partidos locais, ora cediam às conveniências de seus patronos". Ciclo que é quebrado já na primeira eleição republicana. Ibidem, p. 190.

4 Aspecto já apontado por Claudio Batalha em: BATALHA, Claudio H. M. O movimento operário na Primeira 
Alianças entre representantes dos trabalhadores e tradicionais lideranças partidárias não chegavam a ser uma novidade nas dinâmicas políticas daquela época. A existência dessas zonas de conciliação acaba figurando como expressão de certo credo compartilhado na negociação da ação social através do aparato político. A República atualizou os termos desses acordos, e a minha preocupação neste texto é justamente situar as maneiras com que certos grupos de trabalhadores organizados se beneficiaram dos reajustes institucionais promovidos pela mudança de regime. Para tanto, é necessário explorar quem eram esses trabalhadores e o que justificava a crença na ideia de que artistas manuais podiam atuar na linha de frente da política, ou mesmo ocuparem cadeiras no parlamento.

\section{Novas possibilidades e antigas tradições associativas}

Após o 13 DE MAIO, o debate público no Brasil passou por um ponto de viragem com uma rapidez notável. A temática da abolição, em torno da qual uma enorme e complexa estrutura de mobilização havia se organizado por décadas, foi sumariamente substituída nas reflexões da elite política e intelectual pelas problemáticas do trabalho livre. Para outros debates, diferentes categorias, e aqueles que, até então, eram chamados de "libertos", passaram a ser classificados como "trabalhadores nacionais". O hino da Proclamação da República, por exemplo, abordava a questão como um problema superado de um passado distante, "Nós nem cremos que escravos outrora/Tenha havido em tão nobre País...", mas quando Medeiros de Albuquerque o escreveu não fazia sequer um ano que a princesa regente havia assinado a Lei Áurea. ${ }^{5}$

Esse ponto de viragem acabou por balizar o 13 de maio como "um marco temporal separador de 'dois brasis"', que buscava demarcar uma oposição irreconciliável entre escravidão e trabalho livre, como bem assinalou a historiadora Silvia Hunold Lara. ${ }^{6}$ Um processo que pode ser percebido se colocarmos em comparação os significados da "questão social" nos discursos de intelectuais dos anos anteriores e posteriores a $1888 .{ }^{7}$ Era comum que abolicionistas e republicanos pensassem a "questão social" em referência ao conjunto de relações de trabalho sob a escravidão. Em uma circular da Confederação Abolicionista, em favor da candidatura de José do Patrocínio na Corte em 1884, declarava-se, por exemplo, que:

República. Rio de Janeiro: Zahar, 2000. p. 22. Também observado por Aldrin Castellucci para o caso dos partidos operários em Salvador: CASTELLUCCI, Aldrin A. S. Política e cidadania operária em Salvador (18901919). Revista de História (USP), n. 162, $1^{\circ}$ semestre de 2010.

5 Sobre o tema: BORGES, Dain. Intellectuals and the forgetting of slavery in Brazil. Annals of Scholarship, v. 11, n. 1-2, 1996; CARVALHO, José Murilo de. A formação das almas: o imaginário da República no Brasil. São Paulo: Companhia das Letras, 1990. Em especial, o capítulo 5.

6 Nesse artigo clássico, Silvia Lara criticou principalmente o chamado "paradigma da transição", recorte temático e temporal baseado na ideia de que o trabalho livre e o escravo eram campos diferentes de análise e deveriam ser separados pelo marco da abolição. Após o 13 de maio, as relações de trabalho no Brasil deveriam ser entendidas por outra perspectiva orientada para perceber as dinâmicas da ordem capitalista-burguesa, do contratualismo e do trabalho livre. LARA, Silvia Hunold. Escravidão, Cidadania e História do Trabalho no Brasil. Projeto História, São Paulo, n. 16, fev. 1998.

7 O termo "questão social" era essencialmente mutável, englobava um amplo universo de reflexões que iam desde as teses alusivas às relações entre capital e trabalho até doutrinas voltadas ao combate do pauperismo e da miséria. Seus sentidos, portanto, variam de acordo com a situação histórica em que é evocado, dizem respeito fundamentalmente a formas de solucionar problemáticas e tensões emergentes relacionadas à distribuição de riqueza e a busca pela harmonia social. Sobre o tema, ver: CASTEL, Robert. As metamorfoses da questão social: uma crônica do salário. Petrópolis: Editora Vozes, 1998. Para a os primeiros usos do termo e sua conceituação, ver: pp. 30-31. 
A confederação abolicionista tem procurado a solução do problema do trabalho entre nós, esforçando-se por substituir o homem ao escravo, a liberdade à escravidão [...] é em respeito à lei e querendo ficar dentro da lei que resolveu ir pedir às urnas a consagração das suas ideias, pelo sufrágio concedido às suas opiniões representadas na questão social que ora se agita. ${ }^{8}$

Por outro lado, grupos republicanos relacionaram escravidão e questão social para não se comprometerem com a agenda da abolição, como fizeram principalmente os paulistas. ${ }^{9} \mathrm{O}$ principal nome do republicanismo em Pernambuco, o bacharel José Isidoro Martins Júnior, afirmava, em 1887, que a questão social como era concebida na Europa, relacionada à "emancipação do proletariado, ainda não se formulou, porque a massa dos futuros proletários é representada ainda hoje pelos escravos". Mas, continuava, "se quiser considerar a questão dos escravos como a nossa questão do trabalho, então eu tenho o direito de dizer que a reforma capital é a política". Em uma conclusão interessada antes na mudança do regime do que na abolição imediata, fazendo coro com os líderes do Partido Republicano Paulista. ${ }^{10}$

Até 1888, na arena da política institucional, a pauta da regulamentação das relações de trabalho resumia-se quase que completamente à questão da abolição. Quando Joaquim Nabuco, em 1884, fez um discurso em praça pública para uma audiência formada essencialmente por artífices urbanos, ele reafirmava esse aspecto:

A escravidão retardou em dois séculos a emancipação do proletariado nacional, mas hoje, que ele começa a pensar e a querer, é preciso que a sua primeira intimação aos poderes delegados seja a favor dos escravos, de cuja classe em sua maior parte ele saiu. ${ }^{11}$

São declarações que evidenciam que não havia muita disposição entre as lideranças partidárias para que fosse encampada uma agenda programática em torno das pautas do proletariado enquanto houvesse escravidão no país. Cenário que muda tão logo é proclamada a República. Já em março de 1890, publicava-se na Gazeta de Notícias do Rio de Janeiro um artigo sobre esse tópico, onde se afirmava: "Não há, no momento atual, questão alguma de tão vital importância como essa de fazer leis em benefício das classes operárias". ${ }^{12}$ Entre 1890 e 1892, as colunas dos jornais de Recife, do Rio de Janeiro e de outros centros urbanos já anunciavam essa nova fase da "questão social" no Brasil. ${ }^{13}$

8 Manifesto ao eleitorado. Gazeta da Tarde, Rio de Janeiro, 2 set. 1884. São muitos os exemplos de abolicionistas utilizando o termo questão social com esse mesmo sentido; ver, por exemplo: Aos Srs. Eleitores do $1^{\circ}$ distrito. Jornal do Comercio, Rio de Janeiro, 28 out. 1881; Assuntos do dia. Jornal do Recife, Recife, 6 dez. 1880; Alguns traços da época. A Província, Recife, 25 mar. 1873; Gazeta da Tarde, Rio de Janeiro, 12 ago. 1884.

9 COSTA, Milene Ribas da. A implosão da ordem: a crise final do Império e o Movimento Republicano Paulista. Dissertação (Mestrado em Ciência Política) - USP, São Paulo, 2006. p. 54.

10 Mundo político. Revista do Norte, Recife, 20 fev. 1887.

11 NABUCO, Joaquim. Campanha Abolicionista no Recife [eleições de 1884]. Brasília: Ed. Senado, 2005. p. 139. Nesse mesmo discurso, Nabuco chega a apresentar algumas propostas de "proteção" aos trabalhadores, como "leis sociais que modifiquem as condições de trabalho" e "educação profissional", mas salientava que o "primeiro passo é abolir a escravidão".

12 Classe Operária. Gazeta de Notícias, Rio de Janeiro, 27 mar. 1890. A matéria foi originalmente publicada no jornal Eco Popular, de propriedade do tipógrafo França e Silva.

13 Sobre o tema, destaco o debate que se prolongou de maneira um tanto irregular, mas contínua, entre março e setembro, nos jornais do Rio de Janeiro, O Tempo e Gazeta de Notícias, onde diversas teorias relacionadas à "questão social" eram debatidas por José Augusto Vinhaes no primeiro jornal e rebatidas pela redação do segundo. Ao fim, Vinhaes selecionou esses artigos numa brochura e publicou sob o título "Propaganda do 
A mudança de agenda promulgada com a abolição foi um fator favorável à elaboração de projetos voltados aos trabalhadores livres. O processo intensificou-se com a instauração da República, quando balizas normativas garantiram as condições para a organização de uma plêiade de novas sociedades de trabalhadores. ${ }^{14}$ Muitos dos líderes que vieram a representar a base de defesa dos interesses dos trabalhadores já apoiavam o movimento republicano nos anos anteriores a 1889. De alguma maneira, as ideias de propagandistas republicanos como Quintino Bocaiúva e Silva Jardim, que apresentavam uma concepção de república que viria a solapar as hierarquias sociais e acabar com os privilégios, soavam bem aos ouvidos daqueles que pugnavam ideais igualitários, como era o caso dos trabalhadores que compunham a Liga Operária Pernambucana, associação que se pronunciou mais veementemente nesse sentido.

Já em dezembro de 1889, essa coletividade formada por artífices fez publicar reiteradas mensagens de apoio ao novo regime, com o que também procuravam construir alianças e estreitar laços com sociedades congêneres, principalmente com a União Operária do Rio de Janeiro. ${ }^{15}$ Nas imagens que projetavam em seus artigos na imprensa, a crença na chegada de uma nova ordem era expressada pela antítese entre Monarquia e República, fiavam-se na esperança de que por sobre "os resquícios do regime aristocrata" iniciava-se aquele que "veio trazer liberdade às classes laboriosas". Da aniquilação dos "chacais da monarquia" e, por consequência, com o fim "dos privilégios de qualquer natureza", abria-se "um campo vasto" onde cada classe poderia pleitear sua autonomia. ${ }^{16} \mathrm{Na}$ toada desse discurso, conclamavam: "Artistas! Nada temos a esperar de outras classes em nosso favor [...] temos um programa, um ideal; reunamos em nosso grêmio todos os elementos operários". ${ }^{17}$

$\mathrm{E}$, de fato, como mencionado no primeiro parágrafo deste artigo, alguns meses depois esses artistas saíram pelas oficinas do Recife procurando outros trabalhadores dispostos a engrossar a formação de um diretório partidário. Na ocasião, eles distribuíram uma publicação própria, o jornal Gazeta dos Operários, onde apresentavam as pautas que pretendiam encampar e as articulações em torno daquele projeto. ${ }^{18}$ "Trajando a blusa proletária" almejavam "tirar o sono dos que pretenderem, doravante, negar-nos pão, trabalho e justiça como nos tempos do rei”, e listavam um programa de seis pontos, a saber: 1) proibição da contratação de aprendizes que não saibam ler e escrever; 2) oito horas de trabalho nas oficinas; 3 ) medidas preventivas relativas a acidentes de trabalho; 4) redução de horas de trabalho para as mulheres e aumento de salários; 5) elevação de tributos para manufaturas importadas, no caso de já existirem fabricação dos mesmos produtos no

Centro do Partido Operário - Resposta a Gazeta de Notícias". Para o Recife, ver, por exemplo: O magno problema social. Jornal do Recife, Recife, 28 out. 1892; Pedagogia. Jornal do Recife, Recife, 4 nov. 1890. Em 1894, Silvio Romero escreveu uma série de artigos sobre o tema no Jornal do Recife e, naquele mesmo ano, tratou do tema em sua publicação: ROMERO, Silvio. Doutrina contra doutrina: o evolucionismo e o positivismo na República do Brasil. Rio de Janeiro: J. B. Nunes, 1894.

14 Sobre o tema, há ampla bibliografia. Ver, por exemplo: GOMES, Ângela Maria de Castro. A invenção do trabalhismo. São Paulo: Vértice/Editora Revista dos Tribunais; Rio de Janeiro: Instituto Universitário de Pesquisas do Rio de Janeiro, 1988; BATALHA, op. cit.; PANSARDI, Marcos Vinícius. "O movimento operário e a República". Revista Estudos de Sociologia, v. 3, n. 5, 1998.

15 Liga Operária Pernambucana. Diário de Pernambuco, Recife, 8 dez. 1889; Liga Operária Pernambucana. Diário de Pernambuco, Recife, 18 dez. 1889.

16 Ibidem.

17 Ibidem.

18 Gazeta dos Operários, Recife, 15 jul. 1890. A folha trazia em seu slogan: "Órgão das classes artísticas e industriais: a união faz a força". 
estado; 6) democratização dos capitais por meio de caixas econômicas e montepios para os velhos e inválidos do trabalho. ${ }^{19}$

De certa maneira, essa pauta refletia o próprio caráter da formação daquele grupo, combinando influências recentes provenientes das articulações com outras associações e reivindicações de uma pauta internacional do movimento operário, com objetivos e atribuições presentes em organizações mutualistas. A Liga Operária Pernambucana não surgiu com a República - foi fundada em meados de 1886 -, mas foi a partir de 1889 que passou a apresentar na imprensa laços e filiações com organizações operárias de outros lugares do país. Em suas páginas anunciavam as diretrizes de uma luta operária unificada ao redor do mundo, ao que, referiam-se "aos irmãos de além-mar" e à “Liga Operária de New York", mas, do ponto de vista propriamente organizacional, buscavam se filiar às organizações do Rio de Janeiro. ${ }^{20} \mathrm{Em} \mathrm{1889}$, anunciavam conexões tanto com o grupo do tenente José Augusto Vinhaes quanto com o Partido Operário do tipógrafo Luiz França e Silva, chegando inclusive a receber Roberto Kinsman Benjamin em Recife, quando ele desempenhava a função de presidente provisório do Partido Operário em 1890. ${ }^{21}$ É muito provável que o contato com esse conjunto de agremiações e movimentos de outros lugares do mundo tenha não só influenciado a adoção de pautas em torno da redução da jornada de trabalho e por melhores condições de trabalho, mas também inspirado a linguagem utilizada pelo grupo e os símbolos adotados, como a celebração do $1^{\circ}$ de maio e o orgulho em trajar a blusa proletária, em oposição à "aristocrática casaca das classes opulentas". ${ }^{22}$

Já outras questões arvoradas pelo grupo, como a proibição da contratação de aprendizes analfabetos e a realização de iniciativas previdenciárias, trazem à tona uma continuidade de pautas que já vinham sendo empreendidas pelos membros da Liga Operária em suas experiências prévias no universo associativo pernambucano. Há um aspecto específico que a Liga Operária omitia em suas publicações, mas que é fundamental para entender a sua

19 O nosso programa. Gazeta dos Operários, Recife, 15 jul. 1890.

20 Manifesto. Gazeta dos Operários, Recife, 15 jul. 1890.

21 Em Liga Operária Pernambucana. Diário de Pernambuco, Recife, 31 out. 1889, anunciavam que reformariam seus estatutos "segundo as bases do Corpo Coletivo União Operária", a associação fundada por "diversos artistas" do Rio de Janeiro; Liga Operária Pernambucana. Jornal do Recife, Recife, 23 fev. 1888. Contavam em suas fileiras com muitos membros célebres do movimento republicano atuando enquanto conselheiros em meio aos seus quadros consultivos. Esse contato com a agremiação do Rio de Janeiro foi feito inclusive por intermédio do deputado republicano de Pernambuco Alcoforado Junior e do liberal Afonso Celso (que, vale destacar, foi ministro da Marinha no Império); Com a República, suas publicações passaram a fazer referência às lideranças dos partidos operários do Rio de Janeiro. Ver, por exemplo: Liga Operária Pernambucana. Diário de Pernambuco, Recife, 18 dez. 1889; e as matérias da Gazeta dos Operários, Recife, 15 jul. 1890; sobre o Corpo Coletivo União Operária, ver: COSTA, Rafael Maul de Carvalho. A "escravidão livre" na Corte: escravizados moralmente lutam contra a escravidão de fato (Rio de Janeiro no processo da abolição). Tese (Doutorado em História) - UFF, Niterói, 2012. p. 106; BATALHA, Claudio H. M. (org.). Dicionário do movimento operário - Rio de Janeiro do século XIX aos anos 1920, militantes e organizações. São Paulo: Fundação Perseu Abramo, 2009.

22 O nosso programa. Gazeta dos Operários, Recife, 15 jul. 1890. Ao anunciar as comemorações que estavam organizando para o $1^{\circ}$ de maio de 1891, o grupo destacava a influência do movimento operário para justificar a adesão àquela efeméride. Afirmavam que a data simbolizava uma «conquista, um fato inolvidável [...] na Europa, os operários da Alemanha e da França promoveram ruidosas manifestações, que nem sempre tiveram o selo da ordem e tranquilidade», e concluíam que, em Recife, eles também celebrariam a data em comunhão com seus "irmãos de além-mar"; Liga Operária Pernambucana. Diário de Pernambuco, Recife, 2 maio 1889. O recurso à "blusa proletária" era puramente retórico, remontava à indumentária de trabalho de artífices franceses utilizada no século XIX, é pouco provável que o mesmo traje fosse utilizado no Brasil. Sobre o tema, ver: BATALHA, Claudio H. M. A geografia associativa: associações operárias, protesto e espaço urbano no Rio de Janeiro da Primeira República. In.: AZEVEDO, Elciene... [et al.]. Trabalhadores na cidade: cotidiano e cultura no Rio de Janeiro e em São Paulo, séculos XIX e XX. Campinas: Editora da Unicamp, 2009. p. 258. 
existência: até 1890, todos os seus membros trabalhavam nas oficinas do Arsenal da Marinha. Essa opção pela não identificação do grupo com o lugar de trabalho de seus membros era coerente com o projeto de representar todos os artistas e operários da cidade do Recife, de modo que eles se apresentavam simplesmente como artistas, não como artistas do Arsenal. ${ }^{23}$ Os limites e a natureza da atuação da Liga podem ser substancialmente apreendidos a partir de dados levantados através do método de pesquisa nominativo. Investigações em torno dos nomes de 28 operários que faziam parte de sua diretoria e de comissões no ano de 1890 revelam que, além de um perfil social semelhante, uma parte considerável de seus membros já atuava em associações de auxílios mútuos. ${ }^{24}$

Se em 1890 a Liga Operária Pernambucana buscava se aventurar nas tramas eleitorais, antes disso, a associação tinha basicamente um caráter mutualista, baseado na assistência e proteção social a seus sócios. $O$ artigo $2^{\circ}$ de seus estatutos evidenciava que cabia à agremiação socorrer seus afiliados "quando enfermos ou impossibilitados de trabalhar, e contribuir aos seus enterramentos" ${ }^{25}$ Cinco de seus diretores já haviam conduzido uma associação com fins semelhantes no começo dos anos 1880, a Sociedade Artística dos Carpinteiros de Construção Naval, e outros cinco estavam à frente do Montepio Bom Sucesso, esse último, de duração mais longeva, existiu até $1900 .{ }^{26}$

Em seu meticuloso estudo sobre as relações de trabalho no Arsenal da Marinha do Rio de Janeiro, David Lacerda dedicou um capítulo específico a esse tema. Pontuando que, durante a maior parte do século XIX, as mutuais tornaram-se "a principal forma organizativa dos trabalhadores livres após a abolição das corporações de ofício pela Constituição de 1824", e o autor evidencia como essa estrutura associativa foi fundamental para a "construção e o fortalecimento de solidariedades horizontais nos mundos do trabalho". ${ }^{27}$

Só na Corte, os trabalhadores da construção naval chegaram a fundar 12 entidades do tipo entre 1851 e 1901. A profusão desses empreendimentos relacionava-se ao grande contingente de operários que laboravam naquelas oficinas gozando relativa estabilidade enquanto assalariados, mas a expressiva demanda de filiação às mutuais justificava-se principalmente pelas árduas condições de trabalho. ${ }^{28}$ Com jornadas que podiam variar de

23 É importante ressaltar que, a partir da segunda metade do século XIX, as mutuais passaram a deixar de lado a identificação por ofício e profissão, em uma tendência de ampliação de solidariedade horizontal que paulatinamente foi se firmando em torno do conjunto da "classe". LACERDA, David P. Mutualismo, trabalho e política: a seção do Conselho de Estado e a organização dos trabalhadores na cidade do Rio de Janeiro (1860-1882). In.: MAC CORD, Marcelo; BATALHA, Claudio H. M. (org.). Organizar e proteger: trabalhadores, associações e mutualismo no Brasil (séculos XIX e XX). Campinas: Editora da Unicamp, 2014.

24 Os nomes dos 28 trabalhadores que faziam parte da Liga foram extraídos de: Liga Operária Pernambucana. Diário de Pernambuco, Recife, 18 maio 1890; Circular. Jornal do Recife, Recife, 26 jul. 1890.

25 O nosso programa. Gazeta dos Operários, Recife, 15 jul.1890. Em setembro de 1888, a Câmara dos Deputados julgou uma emenda "autorizando o pessoal do Arsenal da Marinha de Pernambuco a organizar Montepio sob as bases que julgarem convenientes [...] cabendo à Liga Operária Pernambucana as atribuições relativas à instituição". Câmara dos Deputados. Diário de Pernambuco, Recife, 22 set. 1888.

26 Da primeira sociedade faziam parte os operários: João Paulo da Pureza (presidente), Luiz de França Praxedes, Manoel Gomes Saraiva, José Fernandes Moreira e David Francisco Gentil. Já na diretoria do Montepio Bom Sucesso: João Baptista de Jesus, Manoel Francisco Pereira da Cunha, José Calasans de Figueiredo, José Francisco das Chagas Ribeiro e Benigno de Figueiredo.

27 LACERDA, David P. Trabalho, política e solidariedade operária: uma história social do Arsenal de Marinha do Rio de Janeiro (c. 1860 - c. 1890). Tese (Doutorado em História) - Unicamp, Campinas, 2016. Para esse parágrafo e o seguinte, foram consultados os capítulos 4 e 5 .

28 Em relação à estabilidade dos artistas do Arsenal da Marinha de Pernambuco, quando esse estabelecimento teve suas atividades encerradas em 1899, contava em suas oficinas com mais de 80 operários que já tinham entre 20 e 42 anos de serviços prestados. Extinção dos arsenais. Jornal do Recife, Recife, 17 jan. 1899. 
10 a 18 horas, em um regime que se estendia de segunda a sábado, em oficinas muitas vezes insalubres, os trabalhadores dos Arsenais viviam expostos a uma rotina de expressiva insegurança e precariedade. Os casos de acidentes nas oficinas eram regulares.

Muitos dos membros da Liga Operária Pernambucana não faziam parte apenas de associações mutualistas de caráter profissional. Dos 28 artistas pesquisados, pelo menos 16 eram membros de irmandades católicas diversas, como as de São José de Ribamar, São Benedito, Nossa Senhora do Rosário e outras que, de uma maneira ou de outra, dividiam suas atividades devocionais com a prestação de serviços de proteção, principalmente de assistência funerária. ${ }^{29} \mathrm{As}$ irmandades citadas remetem ao universo associativo negro do Brasil nos séculos XVIII e XIX. Em torno de irmandades devotadas aos mesmos santos, africanos e seus descendentes se organizaram em diversas partes do país, criando laços identitários próprios e redes de assistência social de maneira ampla e diversa, como a historiografia vem demonstrando nos últimos anos. ${ }^{30}$

Até o começo do século XIX, algumas irmandades também desempenharam um papel fundamental na organização do trabalho, sediando corporações de ofício que detinham o privilégio do ensino das artes mecânicas e o monopólio no fornecimento de produtos e serviços de categorias especializadas. Situação que mudou em 1824, quando a Constituição determinou a extinção das corporações de ofício. A lei suspendia esse tipo de organização, mas, como Marcelo Mac Cord demonstrou em seus estudos, as imposições normativas não tiveram a capacidade de dissipar as práticas e os costumes corporativos dos mestres de ofício em Recife. Mestres carpinteiros, pedreiros, marceneiros e tanoeiros que se organizavam em torno da confraria embandeirada de São José de Ribamar se adequaram à nova realidade normativa, reformando os estatutos da irmandade e fundando uma associação laica, a Sociedade das Artes Mecânicas, que depois veio a se chamar Sociedade Imperial dos Artífices Mecânicos e Liberais. ${ }^{31}$

29 As outras irmandades em que se podem encontrar esses operários em postos de direção são: Nossa Senhora do Bom Parto (da qual faziam parte três dos diretores da Liga), Bom Jesus das Dores, Bom Senhor dos Passos, Santa Cecília, São Crispim e Nossa Senhora do Livramento. Eventuais publicações da imprensa evidenciam laços dos operários do Arsenal com as irmandades. Era comum, por exemplo, que a banda do Arsenal tocasse nas festas de boa parte dessas irmandades. Em 1890, um operário do Arsenal protestou na imprensa contra um capitão que proibiu que fosse feita uma ornamentação no Arsenal em celebração da procissão de quaresma realizada pela irmandade de Bom Senhor dos Passos. Esse operário afirmava que, "há cerca de 16 anos", ele era o "encarregado da ornamentação do altar junto ao Arsenal", e argumentava que sempre encontrou nos "Srs. Inspetores daquele estabelecimento boa vontade e aquiescência". O operário afirmava, por fim, ser "católico apostólico romano, membro de diversas confrarias e irmandades". A chapa. Diário de Pernambuco, Recife, 23 ago. 1890.

30 Para citar alguns títulos: MARTINS, Mônica de Souza N. Entre a cruz e o capital: as corporações de ofício no Rio de Janeiro após a chegada da família real, 1808-1824. Rio de Janeiro: Garamond, 2008; MARTINS, Mônica de Souza N. A prática do auxílio mútuo nas corporações de ofício no Rio de Janeiro na primeira metade do século XIX. In.: MAC CORD, Marcelo; BATALHA, Claudio H. M. (org.). Organizar e proteger: trabalhadores, associações e mutualismo no Brasil (séculos XIX e XX). Campinas: Editora da Unicamp, 2014; REGINALDO, Lucilene. Os rosários dos angolas - irmandades de africanos e crioulos na Bahia setecentista. São Paulo: Alameda, 2011; MAC CORD, Marcelo. O rosário de D. Antônio: irmandades negras, alianças e conflitos na história social do Recife, 1848-1872. Recife: Ed. Universitária da UFPE, 2005; REIS, João José. Identidade e diversidade étnicas nas irmandades negras nos tempos da escravidão. Tempo, Rio de Janeiro, v. 2, n. 3, 1996.

31 Tanto esse parágrafo quanto o seguinte se baseiam em: MAC CORD, Marcelo. Artífices da cidadania: mutualismo, educação e trabalho no Recife oitocentista. Campinas: Editora da Unicamp, 2012. A foto dos membros dessa sociedade também foi tirada desse livro. Algumas das principais teses do livro foram condensadas pelo autor em: MAC CORD, Marcelo. Redes de sociabilidade e política: mestres de obras e associativismo no Recife oitocentista. Revista Mundos do Trabalho, v. 2, n. 4, ago.-dez. 2010. 
As mudanças institucionais garantiram ao grupo um espaço privilegiado de negociação com as elites dirigentes. Capitalizando a ausência de iniciativas do poder público em oferecer ensino profissional, os artífices assumiram esse papel e, a partir da conquista de consideráveis repasses financeiros provenientes do erário público, passaram a oferecer aulas técnicas e de ensino secundário. $\mathrm{O}$ empreendimento, que era gerido sob a égide de uma acentuada moral corporativa, garantiu a esses mestres de ofício respeito e prestígio social, além de algum trânsito pelos círculos de poder na província, o que acabou por garantir ao grupo uma posição proeminente em meio ao mercado de edificações da capital pernambucana. Ainda há uma questão fundamental para entender a importância dessa sociedade: todos os mestres que a geriram durante décadas se declaravam pretos ou pardos.

\section{Imagem I - Membros da Sociedade de Artífices Mecânicos e Liberais em frente ao Liceu}

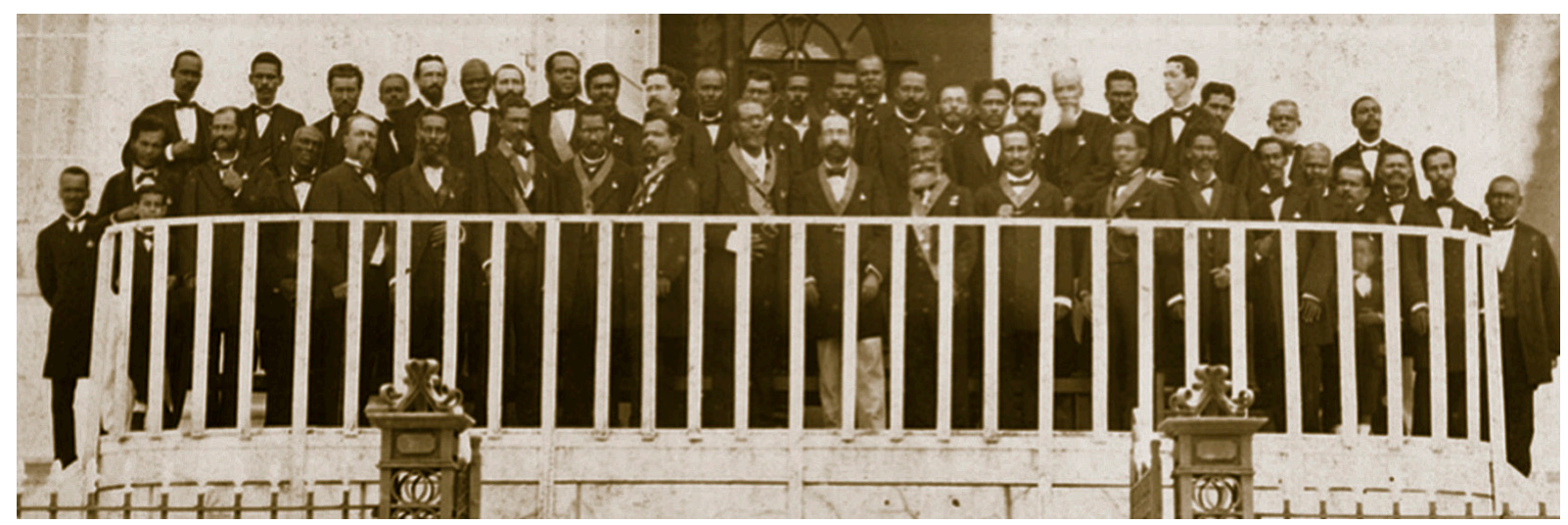

Palacete do Liceu de Artes e Ofícios do Recife. Fotos, Armário 8.2.2. (6), negativo 04340. Rio de Janeiro: Biblioteca Nacional (BN); COSTA, Menna da. Liceu de Artes e Ofícios, PE, 1880: membros da Sociedade dos Artistas Mecânicos e Liberais, detalhe da foto, apud MAC CORD, Marcelo.

Artífices da cidadania: mutualismo, educação e trabalho no Recife oitocentista. Campinas: Editora da Unicamp, 2012.

Essa digressão em torno da história dos artífices não é fortuita, pois muitos dos operários do arsenal passaram pelos bancos do Liceu de Artes e Ofícios, instituição gerida pela Sociedade Imperial dos Artífices Mecânicos e Liberais. E na própria diretoria da Liga Operária Pernambucana havia um conselheiro daquela sociedade. Mas, para além disso, o que pretendo destacar é que o movimento operário em Recife surgiu enquanto ramificação de uma sólida base de experiências fomentadas em um universo associativo essencialmente negro que orbitava em torno de irmandades e confrarias católicas. A investigação dos 28 membros da Liga Operária Pernambucana evidencia a existência de uma rede de trabalhadores negros que se organizavam ao mesmo tempo em associações voltadas à atuação política, social e cultural.

Não deixa de ser simbólico da força das antigas associações que, mesmo depois de passadas tantas décadas desde a proibição das corporações de ofícios, a Confraria de Nossa Senhora do Rosário e a Confraria de São Benedito se mantivessem em atividade até, pelo menos, o começo do século XX, tendo em suas fileiras, ainda na década de 1880, velhos 
africanos..$^{32}$ Pelo menos quatro membros da Liga Operária também faziam parte das diretorias dessas confrarias que, naqueles anos finais do século XIX, se prestavam a fins mutuais e devocionais. ${ }^{33}$ Ainda que essa pesquisa não tenha tido fôlego para buscar na documentação maiores detalhes sobre a rotina dessas confrarias, não passa despercebido o esforço de alguns de seus membros em preservar e difundir a memória de Henrique Dias, o liberto que comandou um batalhão de negros durante a Insurreição Pernambucana e que virou fidalgo após os sucessos nos campos de batalha, conquistando o título de Governador dos Crioulos, Negros e Mulatos. ${ }^{34}$ Afora as festividades que anualmente organizavam diante da capela erguida em homenagem ao herói de guerra, é possível que esses artistas negros também trabalhassem pela manutenção do templo. É o que se presume do artigo publicado pelo operário mecânico, Benigno de Figueiredo, que era síndico da Liga Operária Pernambucana. Em uma pequena coluna do Diário de Pernambuco, ele convocava seus "irmãos católicos" a agirem em apelo à "capelinha cedida ao terço do herói Henrique Dias, [que] está desmoronando": "Negros e mestiços, ide todos vós reconstruir aquele marco sublimado que desaparece da história... Laboremos!" ${ }^{35}$

A luta pelo abolicionismo era outra linha de atuação que se distendia dessas redes de trabalhadores. Em 1888, por exemplo, fundaram o Núcleo Artístico Abolicionista, que após o 13 de maio, quando os objetivos da associação foram alcançados, se tornou o Núcleo Artístico e Instrutivo. O presidente dessa agremiação era o marceneiro Eleutério José dos Santos, que também era membro da mesa da Confraria de Nossa Senhora do Rosário, conselheiro do Montepio Bom Sucesso e fez parte da Liga Operária. Perfil muito semelhante ao de David Gentil, carpinteiro que foi um dos principais articuladores da Liga. Outros membros de irmandades negras também atuavam no Núcleo, mas, ao contrário do que o nome dessa associação pode sugerir, o Núcleo Artístico Abolicionista não era composto apenas de artistas, os bacharéis negros Feliciano André Gomes e Manoel da Motta Monteiro Lopes também compunham seus quadros, o primeiro enquanto orador e o segundo atuando como primeiro secretário. ${ }^{36}$

Irmandades, confrarias, montepios, sociedades abolicionistas, Liceu de Artes e Ofícios, ao longo do século XIX os trabalhadores manuais, com predominância dos pretos e pardos, fundaram e geriram uma série de associações onde conseguiram criar espaços de autonomia em torno de ideais confraternais e laços de solidariedade. ${ }^{37}$ Entre a devoção

32 Os dois confrades africanos se chamavam: Fortunato de Souza Dias, da Confraria de São Benedito, e José da Costa Mina, da Confraria de Nossa Senhora do Rosário. Secretaria da Confraria de São Benedito. Diário de Pernambuco, Recife, 15 maio 1882; Eleição de Confraria. Diário de Pernambuco, Recife, 30 out. 1889; Confraria de São Benedito do Recife. Jornal do Recife, Recife, 30 maio 1905. Confraria de São Benedito. A Província, Recife, 5 ago. 1902. A Província, Recife, 7 out. 1914.

33 A distância em relação à identidade originária dessas confrarias também se expressa na diversidade de trabalhadores urbanos que se faziam representar em seus quadros, mesmo que existisse uma preponderância de artistas mecânicos, havia também em suas fileiras um cozinheiro, um contínuo, um talhador e um jornaleiro. Secretaria da Confraria de Nossa Senhora do Rosário. Jornal do Recife, Recife, 12 jul. 1884.

34 MATTOS, Hebe. Da guerra preta às hierarquias de cor no Atlântico português. In: XXIV SIMPÓSIO NACIONAL DE HISTÓRIA, 2007, São Leopoldo/RS. Anais [...] São Leopoldo: ANPUH(org.)/Unisinos, 2007.

35 Religião. Diário de Pernambuco, Recife, 30 abr. 1905.

36 Núcleo Artístico Abolicionista. Jornal do Recife, Recife, $1^{\circ}$ mar. 1888.

37 Petrônio Domingues utiliza o termo "associativismo negro" para descrever um fluxo muito parecido de atuação coletiva em associações dirigidas por "homens de cor" no Rio de Janeiro. Ainda que com objetivos e formatos diferentes, ele observa que, tanto no Rio de Janeiro quanto em São Paulo, esses grupos tinham princípios comuns voltados para o enfrentamento do racismo e da ampliação de acesso aos direitos da cidadania pela população negra. DOMINGUES, Petrônio. Cidadania por um fio: o associativismo negro no Rio de Janeiro (1888-1930). Revista Brasileira de História, São Paulo, v. 34, n. 67, 2014. Sobre o tema, ver também: PINTO, 
aos seus santos e a administração da vida terrena, conduziram iniciativas que iam do mutualismo à libertação de escravizados, passando por empreendimentos educacionais e de aperfeiçoamento profissional, demonstrando uma notável capacidade de articulação coletiva para o enfrentamento das agruras da vida em uma sociedade escravista e regida pelo primado da discriminação racial. A possibilidade de atuação enquanto protagonistas nas disputas eleitorais, com candidatos próprios e uma pauta afinada com as demandas do movimento operário internacional, sinalizava uma nova fase dessa tradição associativa que se reinventava de tempos em tempos, em uma marcha de ampliação dos limites das estratégias e formas de organização coletiva.

Um aspecto que devo ressaltar é que essas agremiações não conformavam um grupo fechado e homogêneo, elas tinham finalidades e organizações próprias e diferentes entre si. Mas suas diretorias eram formadas por muitos membros em comum e o envolvimento desses indivíduos com irmandades católicas se dava simultaneamente com suas participações em entidades leigas. O caso de Manoel da Motta Monteiro Lopes é um exemplo célebre desse tipo de cooperação associativa. Sua campanha vitoriosa para a Câmara Federal em 1909 foi baseada em um programa voltado à população negra, tendo sido montada em sintonia com os anseios de associações operárias e das irmandades de São Benedito e de Nossa Senhora do Rosário, das quais ele fazia parte. ${ }^{38}$ Seria, portanto, simplificador e precipitado classificar esses trabalhadores negros enquanto um grupo rigidamente coeso. Ainda assim, existiam interlocuções perceptíveis, tanto em termos da defesa do trabalho morigerado, do discurso da solidariedade e das noções compartilhadas de honra e respeitabilidade, quanto da recorrência dos mesmos indivíduos provenientes de um estrato de trabalhadores com um perfil social comum em suas diretorias. O que consegui constatar, a partir da pesquisa nominativa, é que essa porção de trabalhadores que estava à frente das associações citadas eram, no geral, homens, não brancos, artífices, na média dos 40 anos de idade, alfabetizados e, em sua maior parte, eleitores.

Os nomes de praticamente todos os trabalhadores investigados neste texto constam em diversas listas eleitorais de diferentes anos. O envolvimento com a política partidária não rebentou com a República, vinha de antes. Marcelo Mac Cord mostrou como a Imperial Sociedade dos Artífices Mecânicos e Liberais atuou nos bastidores da política com singular desenvoltura, faturando benesses e privilégios a partir de uma estratégia de negociação com líderes partidários. Se até então não haviam conseguido emplacar candidatos representativos de seus próprios grupos, isso diz menos sobre a capacidade de articulação dos trabalhadores do que sobre os limites impostos por uma ordem partidária rigidamente engessada entre os diretórios de liberais e conservadores, muitas vezes organizados em bases familiares. No caso dos membros da Liga Operária Pernambucana, todos tinham direito ao voto e alguns de seus diretores mais antigos chegaram a fazer parte do Club Popular, uma agremiação formada por membros do partido liberal na década de 1870, que tinha "por fim doutrinar o povo nos princípios políticos e sociais". ${ }^{39}$ De modo que, esse indício e outros pontuados ao

Ana Flávia M. Fortes laços em linhas rotas: literatos negros, racismo e cidadania na segunda metade do século XIX. Tese (Doutorado em História) - UNICAMP, Campinas, 2014.

38 DANTAS, Carolina Vianna. Monteiro Lopes (1867-1910): um 'líder da raça negra' na capital da República. Salvador, Afro-Ásia, n. 41, 2010.

39 Para se tornar sócio do Clube, exigia-se apenas duas prerrogativas: o pagamento da mensalidade e que 
longo do texto revelam que uma parte dos diretores da Liga mantinham algum tipo de relação com líderes partidários de Pernambuco.

Com a República, novos horizontes de participação foram abertos. Ao se postarem enquanto aliados do republicanismo, difundindo entre os trabalhadores os ideais mais cândidos dessa forma de governo, os artífices optavam por uma estratégia de aproximação com aqueles que estavam no poder político e que, no final das contas, também dirigiam o Arsenal de Marinha. A fatura desse apoio não tardou a chegar: em meados de 1890, a Liga começou a pleitear suas demandas junto às autoridades políticas. Primeiro, dirigindo uma petição ao "generalíssimo" Deodoro da Fonseca, requisitando que os artistas das repartições públicas passassem a receber remuneração mesmo nos feriados. ${ }^{40} \mathrm{E}$, meses depois, solicitando a redução da jornada de trabalho de calafates e carpinteiros a oito horas diárias, pauta que acabou sendo conquistada não apenas nas oficinas do Arsenal; os diretores da Liga conseguiram negociar a redução de horas também nas docas e estaleiros da iniciativa privada. ${ }^{41}$

O secretário-geral da associação escreveu um artigo exaltando aquela que seria "mais uma vitória para os anais da Liga Operária". Nele, José Francisco Duarte explicava a mudança na carga horária, que deixava de ser das $6 \mathrm{~h} 30$ da manhã às $5 \mathrm{~h} 30$ da tarde, e passava a ser de $7 \mathrm{~h}$ da manhã até $4 \mathrm{~h}$ da tarde, com um intervalo de uma hora para o almoço. O secretário ressaltava que "a índole caracteristicamente filantrópica dos brasileiros assegura às reformas democráticas a mais fácil realização». Tese que seria posta à prova (e refutada) nos anos seguintes, quando o grupo atuou pela expansão da jornada de oito horas para todos os trabalhadores, por meio de campanhas eleitorais e da atuação de políticos vinculados à Liga. ${ }^{42}$

\section{Trabalhadores em cédulas de votação}

Tudo indica que a Liga Operária Pernambucana deixou de ser uma associação exclusiva de artífices do Arsenal da Marinha no momento em que seus membros passaram a bater pernas pelas ruas do Recife distribuindo exemplares da Gazeta dos Operários nas saídas das oficinas. Esse momento, aludido por mim no primeiro parágrafo do texto, sinaliza não só o processo de mudança de perfil da agremiação, que deixava de ser essencialmente uma mutualista e ganhava contornos de partido político, mas também aponta para a incorporação de novos representantes de setores de ofícios urbanos que nada tinham a ver com a construção naval.

Entre 1890 e 1891, o grupo convocou diversas reuniões promovendo uma desejada renovação e ampliação de seus quadros. ${ }^{43}$ As reuniões eventualmente eram dirigidas para categorias específicas, além de cigarreiros e tipógrafos. Em determinada ocasião, o grupo

o indivíduo fosse "reconhecidamente liberal". Estatutos do Club Popular do Recife, Recife, Typographia Mercantil - de C. E. Muhlert \& Cia, 1869. APEJE, Setor de Folhetos Raros, Caixa 16.

40 Jornal do Recife, Recife, $1 \circ$ jul. 1890. Não me foi possível ter certeza se a demanda foi atendida.

41 Pelo menos seis oficinas de empreendimentos privados passaram a implementar a jornada de oito horas. A vitória só foi anunciada em um artigo em: O dia normal do operário. Jornal do Recife, Recife, 22 nov. 1891. Mas, desde junho de 1889 que já havia sido anunciada a "coligação da Sociedade dos Carpinteiros Navais com a Liga Operária Pernambucana". Jornal do Recife, Recife, 29 jun. 1889.

42 O dia normal do operário. A Província, Recife, 22 nov. 1891.

43 Liga Operária Pernambucana. Diário de Pernambuco, Recife, 7 maio 1890; Liga Operária Pernambucana. A Província, Recife, 18 jun. 1890; A Época, Recife, 7 ago. 1890; Jornal do Recife, Recife, 19 mai. 1891. 
buscou reunir mulheres operárias "das fábricas de tecido e de luvas, camisarias, chapelarias e de outras oficinas e casas de modas existentes nesta capital". ${ }^{44}$ Em 1894, mais de 320 operários faziam parte da Liga, dos quais apenas cerca de $25 \%$ eram do Arsenal e das companhias de serviços marítimos. Os demais eram tipógrafos, trabalhadores de fábricas de tecido, de fundição, operários das estradas de ferro e marceneiros. ${ }^{45}$ Por ora, cabe dizer que foi com esse grupo mais diverso que a Liga Operária Pernambucana disputou as primeiras eleições da década republicana, conseguindo eleger inclusive alguns dos seus candidatos.

Em maio de 1891, foram empossados os candidatos eleitos para a primeira legislatura estadual republicana, e entre os deputados destacava-se o "inteligente artista" Jerônimo Telles Júnior, celebrado por alguns pares como "o primeiro representante de sua classe eleito em Pernambuco". ${ }^{46}$ Me refiro a alguns pares porque Telles Júnior estava longe de ser unanimidade entre aqueles que ele pretensamente dizia representar. ${ }^{47}$ Ele não fazia parte da Liga Operária Pernambucana, era então diretor do Liceu de Artes e Ofícios. Em sua juventude, foi maquinista naval e chegou a se aperfeiçoar nas oficinas de limador do Arsenal da Marinha da Corte; nessa instituição assistiu a aulas de desenho e descobriu sua verdadeira vocação, tornandose pintor de quadros. Em idos da década de 1890, Telles Júnior já se encontrava afastado das profissões mecânicas há algum tempo. Desde o início da década anterior, dava aulas de desenho no Liceu e em seu atelier particular, e já gozava de fama enquanto paisagista. ${ }^{48}$

Há no Arquivo Público de Pernambuco uma autobiografia não publicada do artista. Naquelas antigas páginas mimeografadas o autor narra uma série de dissabores e inimizades que cultivou no meio artístico-operário recifense. Sobre o Liceu, afirmava que com malgrado teve que "colaborar com gente de tão baixa esfera e ignorantes, na maior parte analfabetos". Ainda que reconhecesse que "em muito pequeno número [...] havia homens trabalhadores e honestos", insistia que naquela instituição ele se "achava em meio à escória dos operários de Pernambuco". ${ }^{49}$ Quando se tornou diretor do Liceu, as diferenças de Telles Júnior com parte dos membros das classes artísticas e operárias chegaram aos paroxismos, quando ele dizia se sentir fisicamente ameaçado e afirmou que foi "obrigado a andar armado por muito

44 Sobre a filiação das mulheres na Liga, fazia-se uma ressalva exigindo-se que, além de aderir ao programa, as operárias deviam ser "senhoras [...] que constituem família". O interesse era que se formasse ali "uma comissão diretora dentre as associadas para gerir os negócios internos do grêmio e [...] a fim de tratarem sobre os interesses de parte das classes obreiras". Jornal do Recife, Recife, 18 jun. 1890; Liga Operária Pernambucana. A Província, Recife, 18 jun. 1890.

45 Jornal do Recife, Recife, 24 out. 1894. Esses 320 foram apenas aqueles que votaram na eleição interna para eleger qual dos membros da Liga seria o candidato à deputação estadual do grupo.

46 Manifestação honrosa. A Província, Recife, 9 maio 1891.

47 Telles Júnior teve desavenças com membros da Sociedade de Artífices Mecânicos e Liberais, nutriu antipatias com artistas de Olinda e também protagonizou um episódio de discórdia com um grupo de artistas do chamado Congresso Artístico e Operário. Esse grupo também estava organizando uma chapa eleitoral e promoveu algumas reuniões no Liceu, mas Telles Júnior, então diretor do Liceu, os proibiu de continuar com os encontros naquele espaço. Ver: A Sociedade dos Artistas Mecânicos e Liberais. A Província, Recife, 7 mar. 1891.

$48 \mathrm{Na}$ atualidade, Telles Júnior se situa no cânone dos artistas de Pernambuco e seus quadros estão expostos em importantes museus públicos. Em vida, teve relação muito próxima com a aristocracia pernambucana, recebendo jovens aprendizes em seu atelier. Talvez o mais famoso de seus pupilos foi Gilberto Freyre, o sociólogo chegou a pintar um volume considerável de quadros, organizando, inclusive, algumas exposições de suas obras.

49 Telles Júnior não toca em qualquer aspecto racial em seu relato, mas ao tentar compreender suas diferenças em relação ao grupo, me parece que essa é uma questão que deve ser mencionada. Aquela sociedade foi dirigida por artífices negros e pardos por décadas, e é provável que à ocasião tenha sido a primeira vez que um artista branco tenha gerido o Liceu. Sobre sua fisionomia, escreveu o escritor e diplomata Oliveira Lima, na ocasião da morte de Telles Júnior, que o pintor "parecia um holandês, com seu rosto gordo e corado, suas finas barbas loiras...”. Um paisagista pernambucano. Jornal do Recife, Recife, 3 maio 1914. 
tempo". Diante desse cenário, a pergunta mais óbvia que desponta é: como um indivíduo que inspirava tanto ressentimento aos pares podia não apenas ser o candidato da classe, mas também ser eleito com mais de 25 mil votos $?^{50}$

Questionamento que ele próprio explicou em sua autobiografia. Dando a ver que foi uma decisão completamente monocrática, Telles Júnior afirmou que havia no partido autonomista "a ideia de fazer um Congresso onde todas as classes fossem representadas", e seu nome surgiu como indicação de José Mariano, político com quem o pintor havia militado no movimento abolicionista até pouco tempo antes. ${ }^{51} \mathrm{E}$ assim foi, sem o estabelecimento de qualquer diálogo com os grupos organizados do movimento operário, que o primeiro representante da classe artística assumiu um cargo eletivo na Assembleia Legislativa de Pernambuco.

Um arranjo executado nesses moldes acabou por produzir admoestações. Leonel Perigoso era o pseudônimo que assinava uma matéria escrita pretensamente em defesa dos interesses dos "artistas olindenses", na qual se afirmava, em meio a uma série de críticas, que a classe se negou a sufragar o "nariz de cera que o governo lhe quis pôr, incluindo o nome de Telles Júnior entre os que deviam ser nomeados deputados". ${ }^{2}$

Sobre essa última frase, cabe abrir um pequeno parêntese apenas para tecer uma observação sobre a maneira como o autor escreveu que o governo incluiu Telles Júnior entre os que deviam ser "nomeados" deputados. O termo "nomeado", nessa construção, subverte a ideia de que o deputado seria eleito, estabelecendo a premissa de que a vitória daquele candidato já estaria selada independente dos resultados das urnas. O que pode ter sido um deslize na hora de escolher o verbo também pode ser interpretado como uma escolha consciente, com o objetivo de macular aquela candidatura sem bases sociais e imposta de cima para baixo. Em se levando em consideração que a escolha foi consciente, e que os candidatos não eram eleitos, mas sim escolhidos por diretórios governistas, seria lógico pensar que "os artistas olindenses" se abstiveram da farsa eleitoral. No entanto, eles não só fizeram campanha para um candidato próprio (que teve votação pífia), como, ainda segundo o artigo de opinião, selaram "acordos com outros grupos da oposição". É o tipo de indício que evidencia que, mesmo grupos desiludidos em relação ao sucesso de seus candidatos atuavam politicamente, pois os momentos eleitorais, por mais engessados que figurassem em determinadas conjunturas, eram importantes para a mobilização de debates, a conformação de alianças e a construção das diretrizes para a ação social.

Em relação à atuação de Telles Júnior na Câmara, o que se pode dizer é que foi discreta, em muito porque aquela legislatura foi dissolvida com pouco mais de um ano. Mas, nesse

50 A título de comparação do volume da votação que Telles Júnior teve em todo estado, o primeiro governador eleito de Pernambuco teve 27.400 votos nas eleições de 1894 . Agradeço a Marcelo Mac Cord que, com a sua singular generosidade, me colocou em contato não apenas com esse documento, mas com um conjunto documental volumoso e anotações de suas pesquisas anteriores. TELLES JÚNIOR, Jerônimo J. Memórias. Recife: Arquivo Público Estadual, 1954. Datilografado. pp. 13, 14 e 22.

51 Sobre o partido autonomista, cabe afirmar que era uma agremiação alinhada ao governo de Deodoro da Fonseca. Seus laços com o governo se deviam principalmente ao Barão de Lucena que, além de ser ministro e amigo de Deodoro, era o principal articulador do diretório do partido pernambucano. Em seus quadros, o partido assimilou alguns marianistas, membros do antigo partido conservador e um ou outro republicano histórico. Com a ajuda do governo, esse partido saiu vitorioso de todas as eleições que disputou até 1892. Todos os eleitos para cargos estaduais e municipais, no entanto, foram destituídos em 1892, com a queda de Deodoro.

52 Os artistas olindenses. Jornal do Recife, Recife, 30 abr. 1891. Na época, o termo "nariz de cera" era usado com o sentido de "embuste", como pode se ler nos seguintes artigos: Verba escandalosa. Jornal Pequeno, Recife, 14 jun. 1901; A pérola. Diário de Pernambuco, Recife, 12 set. 1896. 
curto período, ele apresentou e colocou em votação "um decreto para fixar em oito, o número de horas de trabalho aos operários e artistas". Se Telles Júnior não foi o candidato da Liga Operária, isso não quer dizer que esse grupo não soube aproveitar da oportunidade de ter no congresso um representante da classe, pois, como a notícia do Jornal do Recife sublinhava, aquele decreto foi apresentado "em nome da Liga Operária de Pernambuco". ${ }^{33}$ O projeto foi aprovado na Câmara, mas essa foi uma vitória muito relativa, visto que, após ter passado por três instâncias de discussão, o decreto acabou sofrendo alterações que lhe extraíam o sentido de lei de proteção social, pois suas determinações legais ficariam submetidas e condicionadas ao acordo entre patrões e operários, valendo, portanto, a prevalência da negociação entre as partes sob o legislado. Mas, mesmo com as modificações o decreto não se tornou realidade, pois foi rejeitado no Senado Estadual tão logo chegou àquela casa. ${ }^{54}$

A cooperação em torno da tentativa de emplacar a lei das oito horas acabou por aproximar Telles Júnior da Liga Operária. O pintor tornou-se sócio honorário e, pouco tempo depois, ele e a sociedade de artistas conciliaram interesses materiais, passando a dividir um sobrado na rua Nova. De dia, aquele prédio no coração da cidade era atelier; em algumas noites, recebia as reuniões dos operários, mas sempre os passantes podiam ver "seu estandarte na varanda" ${ }^{55} \mathrm{~A}$ bandeira da associação também informava um aspecto importante sobre a identidade do grupo, além das explícitas referências republicanas de um pavilhão "organizado à imitação do dos Estados Unidos", contendo no campo azul três estrelas "que significam o lema da corporação - liberdade, trabalho e fraternidade". Havia nessa mesma parte azul um "esquadro e um compasso, símbolos das artes". ${ }^{66}$ Os emblemas do esquadro e do compasso eram representativos do trabalho qualificado. A escolha por esses instrumentos que representavam o rigor e a perícia baseada na técnica, e não outros instrumentos, como, por exemplo, uma foice ou um martelo, dizia algo sobre seus membros fundadores, a maior parte deles mestres em ofícios mecânicos.

Tanto para a eleição da Constituinte quanto para a da Intendência municipal, o grupo lançou uma chapa com os mesmos quatro candidatos. Eram eles: "Arthur de Mello, tipógrafo; Manoel Eugenio da Rocha Samico, perfumista; José Antônio Vieira da Cunha, pedreiro; e Francisco Gomes de Figueiredo, carpinteiro". ${ }^{57}$ Desses, apenas o último tinha vínculos com o Arsenal, onde trabalhou por mais de vinte anos e, à época, desempenhava a função de mestre das oficinas navais.

Os outros três, a despeito dos ofícios artísticos com que se identificavam na circular eleitoral, ocupavam posições de chefia no universo do trabalho. É provável que Arthur de Mello, que aparece como tipógrafo, de fato tenha trabalhado nesse ofício, visto que, em 1891, era orador da União Tipográfica Pernambucana. No entanto, diferentemente da maioria dos seus pares, era bacharel da Faculdade de Direito e tinha alguns fundos, pois, em 1894, se tornou

$53 \mathrm{Na}$ ocasião se encontravam "ocupadas as galerias por grande número de artistas e operários". Horas de trabalho. Jornal do Recife, Recife, 2 set. 1891.

54 Sobre as articulações em torno do decreto da jornada das oito horas, ver: MAC CORD, Marcelo. Direitos trabalhistas em construção: as lutas pela jornada de trabalho das oito horas em Pernambuco, 1890-1891. Tempo, v. 22, n. 39, p. 175-195, jan.-abr., 2016.

55 TELLES JUNIOR, op. cit. p. 19.

56 Liga Operária Pernambucana. Diário de Pernambuco, Recife, 15 maio 1890.

57 Ibidem. 
proprietário de uma folha diária, a Gazeta do Recife. ${ }^{58}$ Outro que possuía empreendimento próprio era Manoel Samico. Ainda que apresentado enquanto perfumista, foi funcionário público ao longo da década de 1880 e, em maio de 1889, foi contemplado pelo governo da província com um privilégio exclusivo de oito anos "para montar nesta cidade uma fábrica de perfumarias e sabonetes". ${ }^{59}$ Por fim, José Antônio Vieira da Cunha, classificado como pedreiro, era um artífice bem relacionado e, naquele ano de 1891, coordenava obras em importantes prédios públicos enquanto "mestre pedreiro da Câmara Municipal e das obras da Academia". ${ }^{60}$

O perfil dos candidatos da Liga era muito semelhante ao dos candidatos dos partidos operários baianos sobre os quais Aldrin Castellucci se debruçou, classificando-os como "aqueles que haviam conseguido uma melhor qualificação profissional e melhor posição material, principalmente na qualidade de mestres de ofícios". ${ }^{61}$ Naquele contexto, como nesse, os precursores do movimento operário eram lideranças que desfrutavam de certo prestígio social fomentado principalmente pela atuação pregressa na vida associativa de irmandades e mutualistas. Nos dois casos, predominou uma agenda conciliatória de negociação e aliança com elites políticas locais. Uma participação no jogo eleitoral voltada antes para a integração do que para o questionamento da ordem estabelecida.

Em relação aos que tiveram sucesso nas urnas, a Liga conseguiu primeiro eleger Antônio Vieira da Cunha, que também fez parte da diretoria da Imperial Sociedade de Artífices Mecânicos e Liberais na década de 1880, o único da chapa que obteve vitória na disputa para a Intendência municipal. No entanto, mesmo tendo conseguido o cargo com um saldo de 2.482 votos, ele acabou sem conseguir assumir o posto eletivo, porque, como já foi dito, as primeiras eleições para prefeito e intendentes foram anuladas após a subida de Floriano Peixoto e o golpe desfechado por uma ala de oposicionistas liderados por republicanos históricos. ${ }^{62}$

Só no ano seguinte, em meio à chapa dos republicanos históricos, a Liga conseguiu emplacar um de seus candidatos. Com mais de 11 mil votos, o perfumista Rocha Samico foi eleito deputado estadual em uma legislatura inteiramente composta por aliados de Martins Júnior. ${ }^{63}$ Naquele congresso formado apenas por membros do partido republicano, Samico não foi uma voz destoante, nem conseguiu articular projetos afinados com as pautas radicais dos programas anteriores da Liga Operária. Aparentemente sua presença tinha mais uma representatividade simbólica de conformação dos elos entre governo e trabalhadores organizados.

A aproximação com os membros da Liga era desejável aos republicanos históricos por uma série de fatores. Em primeiro lugar, as reformas eleitorais do novo regime ampliaram sensivelmente o número de eleitores, principalmente ao suprimir a exigência censitária e

58 União Tipográfica Pernambucana. Jornal do Recife, Recife, 29 dez. 1891.

59 Parte oficial. Diário de Pernambuco, Recife, 17 maio 1889. Sobre sua atuação na Gazeta do Recife: NASCIMENTO, Luiz do. História da imprensa de Pernambuco (1821-1954) - Diários do Recife 1829-1900. Recife: Imprensa da UFPE, v. II, 1966. p. 346.

60 Nessa eleição que saiu vitorioso, houve inclusive uma acusação de que policiais andaram visitando as casas dos eleitores do bairro de Santo Amaro e os ameaçando caso não sufragassem o nome de Vieira da Cunha. Cabala policial. Jornal do Recife, Recife, 30 set. 1891. Enquanto membro da Sociedade dos Artífices Mecânicos e Liberais e do Liceu de Artes e Ofícios, ver: Diário de Pernambuco, Recife 24 jan. 1884; Jornal Pequeno, Recife, 30 nov. 1903.

61 CASTELLUCCI, op. cit. p. 240. Do mesmo autor, ver também: CASTELLUCCI, Aldrin A. S. Trabalhadores e política no Brasil: do aprendizado do Império aos sucessos da Primeira República. Salvador, Eduneb, 2015.

62 Os resultados daquela votação podem ser encontrados em: A Província, Recife, 2 out. 1891.

63 Câmara dos Deputados. Jornal do Recife, Recife, 12 abr. 1892. 
todo o emaranhado burocrático a que os eleitores estavam submetidos para comprovação de renda. Estudos recentes evidenciam que nos centros urbanos esse aumento se deu de maneira mais acentuada, e a observação da oscilação de eleitores entre 1884 e 1903 em algumas freguesias do Recife me leva a afirmar o mesmo. ${ }^{64}$ Enquanto a população da cidade se manteve praticamente estável nesse período, em algumas localidades, como Graças, o eleitorado quintuplicou, na Várzea ele mais que quadriplicou:

Tabela I/Gráfico I - Número de eleitores por freguesia em Recife nos anos de 1884 e $1903^{65}$

\begin{tabular}{c|c|c}
\hline Freguesias & $\mathbf{1 8 8 4}$ & $\mathbf{1 9 0 3}$ \\
\hline Boa Vista & 1.061 & 2.488 \\
\hline Graças & 293 & 1.864 \\
\hline Poço da Panela & 307 & 380 \\
\hline Várzea & 83 & 471 \\
\hline
\end{tabular}

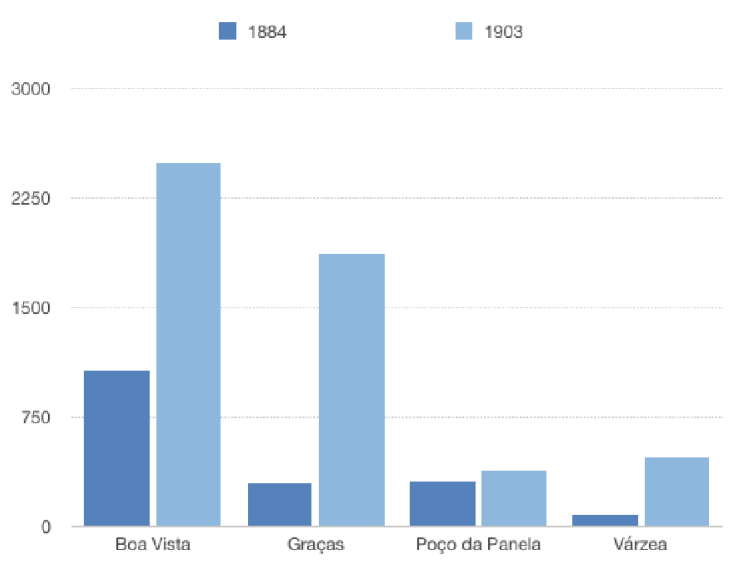

Diante desses dados, é muito provável que as lideranças partidárias ambicionassem uma aproximação com grupos de trabalhadores organizados, com o propósito de capilarizar suas bases de apoio e ampliar seu raio de influência em meio a novos setores do eleitorado que passaram a gozar dos direitos políticos. A Liga Operária era uma associação em expansão e, como já mencionei, em 1894 tinha em seus quadros artistas que representavam todos os principais ramos de indústria de Pernambuco.

Esses mesmos ramos fizeram parte de uma inédita onda de greves em Recife. Os primeiros anos da década de 1890 foram profusos em conflitos trabalhistas que extrapolaram as portas das fábricas e oficinas, tomando as ruas e as colunas de opinião. ${ }^{66}$ Uma conjuntura de lutas sociais que tangenciou os trabalhadores a irem ao encontro das autoridades estatais em um movimento que exigia a intermediação do governo nas relações de trabalho.

Esse processo de ampliação das atribuições sociais dos agentes do estado não partiu apenas das exigências dos trabalhadores organizados, pois muitos patrões e diretores de empresas e indústrias também solicitaram intervenção arbitral do governo em momentos de

64 Para Salvador, São Paulo e Rio de Janeiro, ver: CASTELLUCCI, op. cit. p. 207; PINTO, op. cit. p. 258; CARVALHO, José Murilo de. A construção da ordem: a elite política imperial. Teatro de sombras: a política imperial. Rio de Janeiro: Civilização Brasileira, 2003. p. 395.

65 Para os eleitores de 1884, foi consultado o folheto Qualificação dos eleitores da Boa Vista 1884, acessível no setor de folhetos raros do Arquivo Público Jordão Emerenciano. Para o eleitorado de 1903, consultei as edições de julho e agosto de 1903 do Diário de Pernambuco. Sobre a população de Recife ter se mantido estável, indico a consulta das séries estáticas disponíveis no site do IBGE. Esses dados indicam que, em 1872, Recife possuía cerca de 116 mil habitantes; já em 1900, o número cai para 113 mil.

$66 \mathrm{Em}$ trabalho anterior, computei a eclosão de pelo menos 31 greves em Recife entre 1890 e 1894. Ao longo de toda a década de 1880 , achei referências a apenas quatro greves na cidade. 
impasse. Em meio a essas transações, houve uma perceptível aproximação entre líderes do movimento operário e dos partidos políticos, que acabaram por pactuar alianças veladas e atuações em projetos comuns.

Ponderando para os casos de países do hemisfério Norte, como França, Inglaterra, Alemanha e Estados Unidos, o historiador William Sewell Jr. Afirmou, há algum tempo, que o movimento operário surgiu das oficinas artesanais. ${ }^{67}$ No Brasil, deu-se o mesmo e, no caso específico de Recife, como busquei demonstrar neste artigo, o que ocorreu foi uma remodelação de práticas associativas tradicionais. ${ }^{68}$ Artistas qualificados à frente de grupos de trabalhadores organizados aproveitaram-se das brechas abertas pelas mudanças no cenário político com a República, e pela atualização das reflexões em torno das questões sociais, como a abolição da escravidão, para planejar voos mais altos.

A Liga Operária Pernambucana, capitaneando esse movimento, buscou mudar as feições do estamento político e imprimir as aspirações por justiça social em meio ao corpo de leis estaduais. Para tanto, optou por estratégias de atuação voltadas à cooperação e negociação com as elites, conseguindo resultados modestos se analisados isoladamente, mas notáveis se postos em perspectiva. Ao mesmo tempo, deram uma nova cara ao associativismo ao evocar um idioma de classe e não mais de ofício, fazendo coro com as lutas de trabalhadores de além-mar. Essas inovações em termos de linguagem, símbolos e pautas foram, em pouco tempo, demarcando diferenças entre o associativismo operário e aquele mais tradicional praticado há mais de um século e que tinha suas raízes nas corporações de ofícios e irmandades religiosas.

Recebido em 13/02/2020

Aprovado em 12/03/2020

67 SEWELL, William H. Work and revolution in France. Nova York: Cambridge University Press, 1980. p. 1. Sobre o tema, Eric Hobsbawm afirmou que, na Europa, "os homens que formavam as organizações operárias eram, em grande medida, trabalhadores em ofícios especializados, educados e socializados na tradição do ofício e, nesse sentido, essas tradições ajudaram a moldar as do trabalhismo moderno". HOBSBAWM, Eric J. Mundos do Trabalho: novos estudos sobre História Operária. Rio de Janeiro: Paz e Terra, 2000. p. 103.

68 BATALHA, Claudio H. M. O movimento operário na Primeira República. Rio de Janeiro: Zahar, 2000. 